\title{
Spectroscopic and microscopic study of alkali activated mortars based on Tunisian phosphate washing waste
}

\author{
R. Dabbebi ${ }^{\text {a,b, }}$, J.L. Barroso de Aguiar ${ }^{\mathrm{b}}$, S. Baklouti ${ }^{\mathrm{a}}$ \\ ${ }^{a}$ University of Sfax, Laboratory of Industrial Chemistry, Sfax, 3038, Tunisia \\ ${ }^{\mathrm{b}}$ University of Minho, C-TAC Research Centre, Guimarães, 4800-058, Portugal
}

\section{A R T I C L E I N F O}

\section{Keywords:}

Phosphate washing waste

Calcination

Alkali activated mortars

MAS-NMR

FTIR

\begin{abstract}
A B S T R A C T
The calcination of phosphate washing waste has a significant effect on the microstructure and mechanical properties of the phosphate washing waste-based alkali activated mortars. This study aims to investigate the reaction products of the phosphate washing waste activated with sodium hydroxide (SH) and sodium silicate (SS) with mass ratio of the two solutions $\mathrm{SH} / \mathrm{SS}=1$.

Different techniques were used to characterize the obtained mortars including: Compressive strength, X-ray diffraction XRD, Solid state magic angle spinning nuclear magnetic resonance (MAS-NMR) of 3 nuclei $\left({ }^{27} \mathrm{Al}\right.$, ${ }^{29} \mathrm{Si}$ and ${ }^{31} \mathrm{P}$ ), attenuated total reflectance Fourier transform infrared spectroscopy (ATR-FTIR) and Electron microscope scanning and energy dispersive spectroscopy (SEM-EDS). The obtained results reveal that the alkali activation of phosphate washing waste generate 2 types of reactions and 2 types of products (N-A-S-H)/(C,N)-A-S-H as $3 \mathrm{D}$ network and $\mathrm{C}-\mathrm{S}-\mathrm{H} / \mathrm{C}-(\mathrm{A})-\mathrm{S}-\mathrm{H}$ as $2 \mathrm{D}$ gel. The $\mathrm{Al}$ and reactive Ca have a strong effect on the final mechanical properties.
\end{abstract}

\section{Introduction}

Phosphate rock contains a high concentration of phosphate mineral to be mined commercially [1]. At the international level, the production of this ore attains 147 million tons in 2017 and it will increase to achieve 168 million ton in 2021 [2]. The extraction of $\mathrm{P}_{2} \mathrm{O}_{5}$ ore generates unwanted gangue minerals as waste. Two types of waste can be determined, the waste rock after mining and the phosphatic tailing after mineral processing $[1,3,4]$. The phosphate tailing also named phosphate washing waste or phosphate sludge is generated with a large quantity: 1 ton of ore generate about 1 ton of tailing waste [5-9]. This waste is deposited in a large tailing pound and cause a serious environmental problem like, covering vast areas, elution of phosphate, fluorine and metal in the sediments, water and marine organisms $[10,11]$. For a sustainable management, the recycle, valorization and reuse of this waste will be one of the greatest challenges. Therefore, the phosphate washing waste has been an issue in the last decade. The phosphate washing waste was used in a wide range of field to reduce its environmental problem. In the field of building materials, the phosphate waste was used as a geopolymeric binder and alkali activated materials [12-15] or in the cemented backfill domain [16-18]. This mining waste was investigated also in the field of ceramic, in the development of bricks $[19,20]$ or membranes [21,22] and in heavy metal recovering [23-25].

Turning now to other environmental problem which is the production of cement. The production of this material reached 4.1 billion tons in 2017 [2]. The emission of 1 ton of $\mathrm{CO}_{2}$ per 1 ton of OPC is the worst-case scenario. This production contribute with approximately $5-7 \%$ of global anthropogenic $\mathrm{CO}_{2}$ emissions [26,27]. As a solution, researcher found a new material during the last decades which are the alkali activated materials (AAM). Those materials can be divided in 2 categories based on the method of synthesis. First category corresponds to the material which is based on the activation of aluminosilicates precursors by an alkali solution sodium/potassium hydroxide with or without sodium/Potassium silicates [28-30]. The second category named one part alkali activated materials "just add water" which is a formulation based on the activation of the precursors with solid alkaline activators [31-33]. It has previously been studied that the precursors can be divided into three categories [34-36] according to the calcium content of the binder. Low-calcium precursors like fly ash class $\mathrm{F}$ or metakaolin [28-30] in which the main binding is the 3 dimensional amorphous aluminosilicate named "geopolymer". High calcium based

\footnotetext{
* Corresponding author. University of Sfax, Laboratory of Industrial Chemistry, Sfax, 3038, Tunisia.

E-mail address: dabbebi.rawia.etud@fss.usf.tn (R. Dabbebi).
} 
on blast furnace slag or also fly ash class C [37-39] and this category has calcium silicate hydrate $\mathrm{C}-\mathrm{S}-\mathrm{H}$ as the main binding. Other class designated as intermediate or hybrid materials characterized by the presence of the 2 types of gel "geopolymer" and C-S-H [40-42].

The aim of this study is to explore the relation between the reactivity and the microstructure of the alkali activated materials based on calcined phosphate washing waste, examined using various experimental techniques (XRD, MAS-NMR, FTIR-ATR and SEM-EDS) in order to study the complexes reactions of the binder.

\section{Materials and methods}

\subsection{Materials}

The phosphate washing waste ( $P W W$ ) was provided by Gafsa Phosphate Company (CPG) from (Lavrie (IV)) Metlaoui (Tunisia). The waste was characterized by the high amount of Silicon $42 \mathrm{wt} \%$, Calcium $26.5 \mathrm{wt} \%$, Phosphorus $10 \mathrm{wt} \%$ and Alumina $9.77 \mathrm{wt} \%$. The powder was investigated with different technics discussed in a previous work [43]. The mineralogical study shows that the phosphate washing waste present the calcite, heulandite, palygorskite and carbonate fluorapatite as major phases and display also the presence of gypsum and quartz. The powder was calcined for $2 \mathrm{~h}$ with heating rate $10^{\circ} \mathrm{C} / \mathrm{min}$ from room to the target temperature $600{ }^{\circ} \mathrm{C}, 700{ }^{\circ} \mathrm{C}$ and $800^{\circ} \mathrm{C}$ to be studied for alkali activation. The choose of these temperatures was based on the DSC-TG analysis which present the interval of the decarbonation phenomena in this range of these temperatures.

The alkali activated mortars based on phosphate washing waste were prepared by the use of sodium hydroxide $\mathrm{NaOH}(10 \mathrm{M})$ and sodium silicate solution $\mathrm{Na}_{2} \mathrm{SiO}_{3}$ with chemical composition $\mathrm{Na}_{2} \mathrm{O}\left(\mathrm{SiO}_{2}\right)_{\mathrm{x}}$. y $\left(\mathrm{H}_{2} \mathrm{O}\right)$ with $3.19<\mathrm{x}<3.53$ and $50 \%<\mathrm{y}<60 \%$ from the Portuguese Industry MER-KANDA. The mass ratio of the 2-alkali solution is of the order of 1 . The aggregate used for the preparation of these alkali activated mortars was a sand with particle size distributed with maximum and minimum grain diameters of approximately $8 \mathrm{~mm}$ and $0.2 \mathrm{~mm}$, respectively and just $2 \%$ of the particles are with a size superior to $4 \mathrm{~mm}$. A detailed preparation procedure of this alkali activated mortars was described in a previous work [13]. As a result, the Alkali Activation of phosphate washing waste calcined at $800^{\circ} \mathrm{C}\left(A A P_{800^{\circ} \mathrm{C}}\right)$ presents a problem of the quick setting. Therefore, only the $A A P_{600^{\circ} \mathrm{C}}$ and $A A P_{700^{\circ} \mathrm{C}}$ will be studied in this work.

\subsection{Analytical techniques}

The XRD analysis was conduct for uncalcined and calcined powders and also for the samples at 7 and 28 days. For the MAS-NMR and FTIR (ATR) characterization, the mortars were crushed by hand and sieved to eliminate the aggregate. The SEM-EDS characterization was conduct at 28 days without any special preparation of the samples.

The identification of the phases present in the samples was performed by powder X-ray diffraction XRD Bruker $\mathrm{D}_{8}$ Discover using Cu K $\alpha$ radiation $\mathrm{k}=1.54060 \AA$ at $40 \mathrm{kV}$ and $40 \mathrm{~mA}$ in the range from $5^{\circ}$ to $60^{\circ}$ with a step width of $0.02^{\circ}$ at a speed of $0.02^{\circ} \mathrm{s}^{-1}$ and a front-loading preparation method of the samples. Phase identification was done using X'Pert Highscore software.

The solid-state magic angle spinning nuclear magnetic resonance of the samples were carried out using high resolution UXNMR, Bruker Analytische Messtechnik GmbH AM $\times 300$ spectrometer. Parameters for each experiment are outlined in Table 1. All data were processed using MestreNova.

An attenuated total reflectance Fourier transform infrared spectroscopy (ATR-FTIR) spectra was performed from 400 to $4000 \mathrm{~cm}^{-1}$ wavenumbers using the Fourier Infrared model PerkinElmer spectrum BX spectrometer and the spectra were collected from 4 scans at resolution $2 \mathrm{~cm}^{-1}$ and no special preparation of the samples were needed. The data were processed using Origin Pro software.

The microstructure analysis of the samples was executed using a scanning electron microscope SEM 200 operating at $15 \mathrm{kV}$ An X-ray energy dispersive (EDX) detector was used to determine chemical compositions of different zones for the samples cured for 28 days.

\section{Results}

\subsection{Compressive strength}

Compressive strength is the most important property of building materials. Fig. 1 shows the compressive strength of the two mortars at 7 and 28 days which indicate that the two samples react differently. The compressive strength of the $A A P_{600^{\circ} \mathrm{C}}$ and $A A P_{700^{\circ} \mathrm{C}}$ show a significant difference at 7 days of curing it is about $3.6 \mathrm{MPa} \pm 0.09$ and $5.99 \pm 0.02 \mathrm{MPa}$ for $A A P_{600^{\circ} \mathrm{C}}$ and $A A P_{700^{\circ} \mathrm{C}}$ respectively. At 28 days the two mortars present different results, the compressive strength of $A A P_{600} \mathrm{C}$ increase slightly and become $4.9 \pm 0.14 \mathrm{MPa}$ which is equal to $36 \%$, while the $A A P_{700^{\circ} \mathrm{C}}$ exhibits a compressive strength that increase to achieve $10.7 \pm 0.12$ and it is about $81 \%$. This difference is mainly due to the precursors before and after alkali activation.

\section{2. $X$-ray diffraction}

The X-ray diffractograms of the untreated $P W W$ and calcined at 600 , $700{ }^{\circ} \mathrm{C}$ and the $A A P$ cured for 7 and 28 days are presented in Fig. 2 (A, B and $\mathrm{C}$ ). The $P W W$ and its mineralogy before and after calcination were intensively discussed in a previous work [43]. As presented in Fig. 2A, the uncalcined $P W W$ is characterized by the presence of the heulandite, palygorskite, calcite, carbonate fluorapatite, gypsum and quartz. After

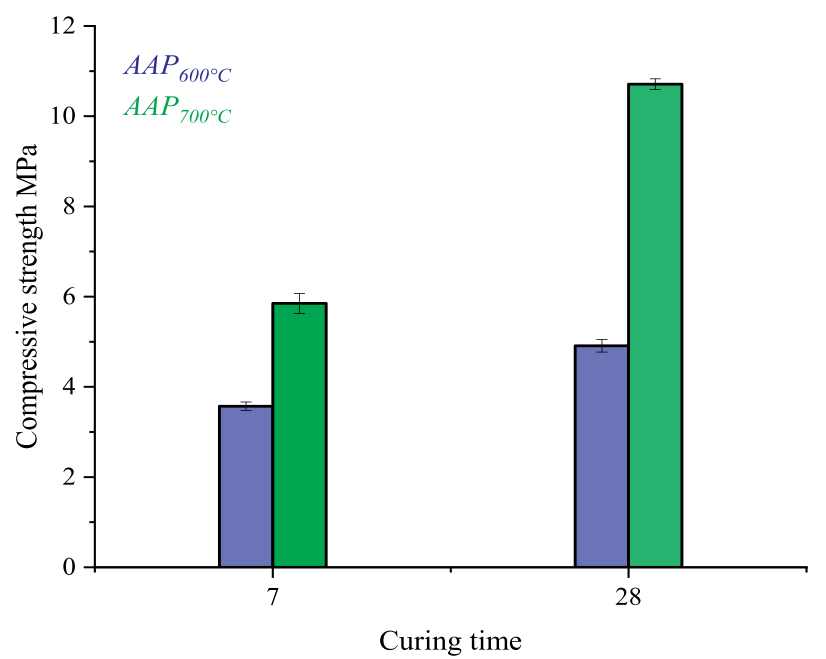

Fig. 1. Compressive strengths of $\mathrm{AAP}_{600^{\circ} \mathrm{C}}$ and $\mathrm{AAP}_{700^{\circ} \mathrm{C}}$ at 7 and 28 days.

Table 1

Parameters MAS-NMR experiment.

\begin{tabular}{llllllll}
\hline Nucleus & Field Strength & Transmitter frequency MHz & n/2 pulse width $(\mu \mathrm{s})$ & Relaxation delay $(\mathrm{s})$ & Scans & Spinning speed $\mathrm{KHz}$ & reference \\
\hline${ }^{29} \mathrm{Si}$ & 7.1 & 59.63 & 5 & 5 & 11524 & 8 & \\
${ }^{27} \mathrm{Al}$ & 7.1 & 78.21 & 6 & 5 & 4168 & 8 & TMS \\
${ }^{31} \mathrm{P}$ & 7.1 & 121.49 & 3 & 5 & 1024 & 8 & AlCl3.6H2O \\
\hline
\end{tabular}



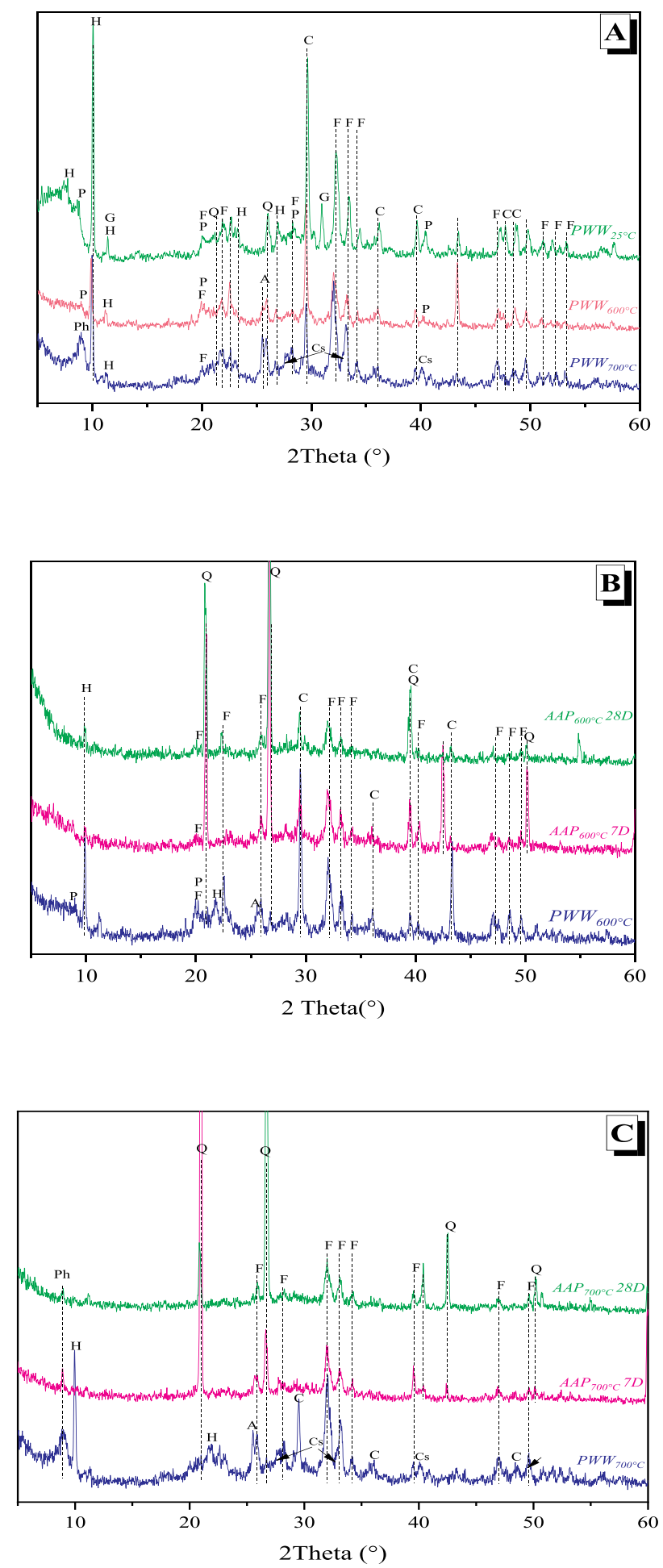

Fig. 2. XRD diffractograms of (A) untreated $\mathrm{PWW}$ and calcined at $600{ }^{\circ} \mathrm{C}$ and $700{ }^{\circ} \mathrm{C} \mathrm{(B)} \mathrm{PWW}_{600^{\circ} \mathrm{C}}$ and $\mathrm{AAP}_{600^{\circ} \mathrm{C}}$ at 7 and 28 days (C) $\mathrm{PWW}_{700^{\circ} \mathrm{C}}$ and $\mathrm{AAP}_{700}{ }^{\circ} \mathrm{C}$ at 7 and 28 days.

F: carbonate fluorapatite (PDF\#:00-002-

0833), H: heulandite (PDF\#:01-076-

2214), P: palygorskite (PDF\#:00-029-

0855), C: calcite (PDF\#:00-002-

0629), G: gypsum (PDF\#:00-021-

0816), Q: quartz (PDF\#:01-070-

2535), Ph: phlogopite (PDF\#:00-079-

2364),Cs: $\mathrm{C}_{2}$ S (PDF\#:00-023-1042), A: anhydride (PDF\#:00-003-0368). calcination at $600{ }^{\circ} \mathrm{C}$ the pattern presents the decrease of the reflection of heulandite, calcite and palygorskite. The reflection of the gypsum disappears and other appear correspond to the anhydride. At $700{ }^{\circ} \mathrm{C}$, the powder shows the disappearance of palygorskite. The reflection of heulandite and calcite decrease more. The pattern displays also new phases like the phlogopite and $\mathrm{C}_{2} \mathrm{~S}$. At the two-calcination temperature the reflections of carbonate fluorapatite and quartz remain stable.

After alkali activation, the patterns of the $A A P_{600^{\circ} \mathrm{C}}$ presented in Fig. 2B, with the cutoff of the $y$-axis because of the higher intensities of quartz, indicating the consumption of the palygorskite, heulandite and anhydride but the carbonate fluorapatite and quartz remain unaltered after the alkali activation. The curves show also the halo centered at about $29^{\circ}$ (2Theta) displaying the formation of the disordered reaction product characteristic of alkali activated materials [33,39,42,44]. The $A A P_{700^{\circ} \mathrm{C}}$ present also the same behavior showed by the $A A P_{600^{\circ} \mathrm{C} .}$ it exhibits the diminution of all the reflection correspond to the calcite, phlogopite, heulandite, $\mathrm{C}_{2} \mathrm{~S}$ and anhydride and indicates also the non-reactivity of quartz [33,44] and carbonate fluorapatite in alkali medium. While, as displayed in Fig. 1 the two samples present a different mechanical strength at 7 and 28 days, which point out that the two $P W W$ react differently after alkali activation. In this case the $A A P$ need to be investigated with other technics to understand more their chemical behavior.

\subsection{Solid state magic angle spinning nuclear magnetic resonance}

The ${ }^{27} \mathrm{Al}$, 29Si and ${ }^{31} \mathrm{P}$ MAS-NMR of the precursors at different temperatures are presented in Fig. 3A and Fig. 5A and Fig. 4B respectively. The results are discussed in detailed in a previous work [43]. The patterns of ${ }^{27} \mathrm{Al}$ nuclei (Fig. 3A) present 2 environments 4-coordinated noted ${ }^{\mathrm{IV}} \mathrm{Al}$ and 6-coordinated noted ${ }^{\mathrm{VI}} \mathrm{Al}$ which show a difference after thermal treatment. The patterns of the ${ }^{29} \mathrm{Si}$ (Fig. 4A) nuclei present different environments of the silicon presented in the different phases of the $P W W$. The ${ }^{31} \mathrm{P}$ nuclei (Fig. 5A) displays one peak corresponds to the phosphorus presented in the carbonate fluorapatite. This peak did not show a difference with the calcination temperature. Table 2 presents the ${ }^{29} \mathrm{Si},{ }^{27} \mathrm{Al}$ and ${ }^{31} \mathrm{P}$ MAS-NMR peaks of the $P W W$ at $25^{\circ} \mathrm{C}, 600^{\circ} \mathrm{C}$ and $700{ }^{\circ} \mathrm{C}$.

The solid-state NMR was designed also to understand the reactivity of the $P W W_{600^{\circ} \mathrm{C}}$ and $P W W_{700^{\circ} \mathrm{C}}$ after the alkali activation $(A A P)$ at 7 and 28 days.

\section{4. ${ }^{29}$ Si-NMR spectroscopy of the AAP}

Comparing the spectra of $A A P_{600} \mathrm{C}$ and $A A P_{700} \mathrm{C}$ at 7 and 28 days with that of calcined $P W W$, an important shift of the spectrum is detected. The obtained spectrum, fitted peak and the deconvoluted results of $A A P_{600^{\circ} \mathrm{C}}$ and $A A P_{700^{\circ} \mathrm{C}}$ are presented in Fig. 6 and Fig. 7 respectively.

As can be seen from Fig. 4B, the curves $\left({ }^{29} \mathrm{Si} \mathrm{MAS-NMR}\right)$ of $A A P_{600^{\circ} \mathrm{C}}$ at 7 and 28 days show an important shift compared to the inactivated powder $P W W_{600^{\circ} \mathrm{C}}$. It displays a chemical shift between - 75 and $-107 \mathrm{ppm}$. The curves show the consumption of the framework with no bonded $\mathrm{Al}$ correspond to $\mathrm{Q}^{4}(0 \mathrm{Al})$ at -111 and $-113 \mathrm{ppm}$. The peaks which correspond to the heulandite phase -95 and $-101 \mathrm{ppm}$ assigned to $Q^{4}(2 \mathrm{Al})$ and $\mathrm{Q}^{4}(1 \mathrm{Al})$ respectively were also consumed. The $\mathrm{Q}^{3}(\mathrm{mAl})$ environment of the palygorskite presented by the peaks at about -91 and $-96 \mathrm{ppm}$ were also altered and new peaks were detected, indicating the formation of new phases during the curing time, while the peak at $-107 \mathrm{ppm}$ corresponds to $\mathrm{Q}^{4}(\mathrm{OAl})$ related to the structure unit from quartz remain constant indicating its low reactivity.

Upon the alkali activation of $P W W_{600^{\circ} \mathrm{C}}$ new signals between -75 and -100 ppm appear as presented in Fig. 6 . These peaks are assigned to new environments of $\mathrm{Si}$ with 3 clear groups. First group of chemical shift has occurred from $-75 \mathrm{ppm}$ to $-81 \mathrm{ppm}$, second group from $-83 \mathrm{ppm}$ to $-87 \mathrm{ppm}$ and a third group of chemical shift from $-91 \mathrm{ppm}$ to 


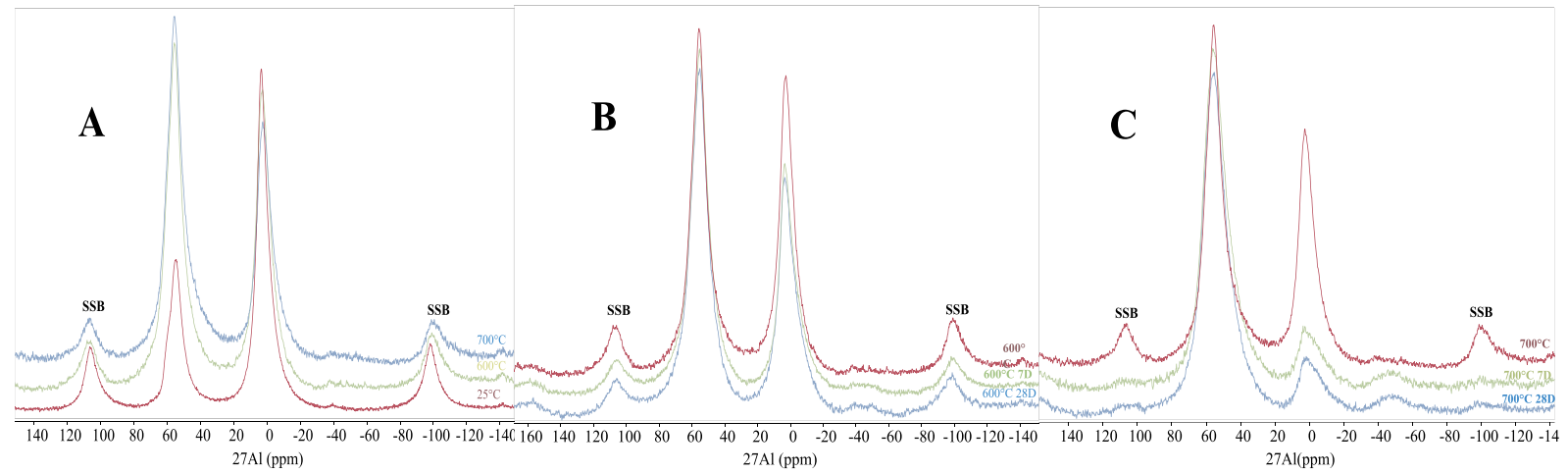

Fig. 3. ${ }^{27} \mathrm{Al}$ MAS-NMR of the PWW (A) at different temperatures, (B) $\mathrm{PWW}_{600^{\circ} \mathrm{C}}$ and $\mathrm{AAP}_{600^{\circ} \mathrm{C}}$ at 7 and 28 days, (C) $\mathrm{PWW}_{700^{\circ} \mathrm{C}}$ and $\mathrm{AAP} 700^{\circ} \mathrm{C}$ at 7 and 28 days.

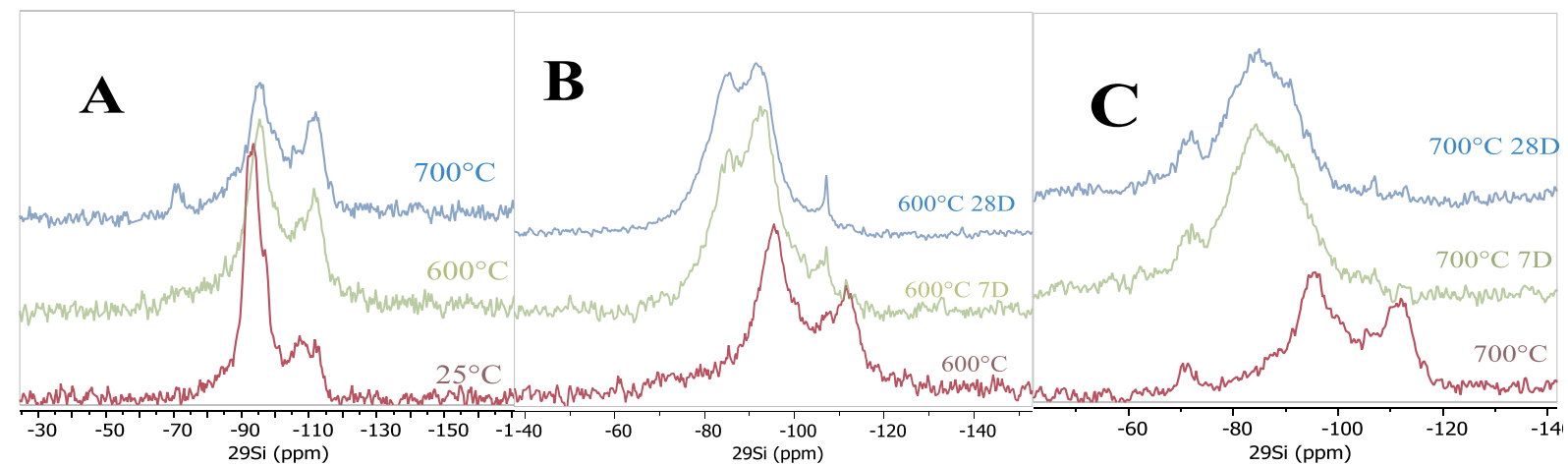

Fig. 4. ${ }^{29} \mathrm{Si}$ MAS-NMR of the PWW (A) at different temperatures, (B) $\mathrm{PWW}_{600^{\circ} \mathrm{C}}$ and $\mathrm{AAP}_{600^{\circ} \mathrm{C}}$ at 7 and 28 days, (C) $\mathrm{PWW}_{700^{\circ} \mathrm{C}}$ and $\mathrm{AAP}_{700^{\circ} \mathrm{C}}$ at7 and 28 days.

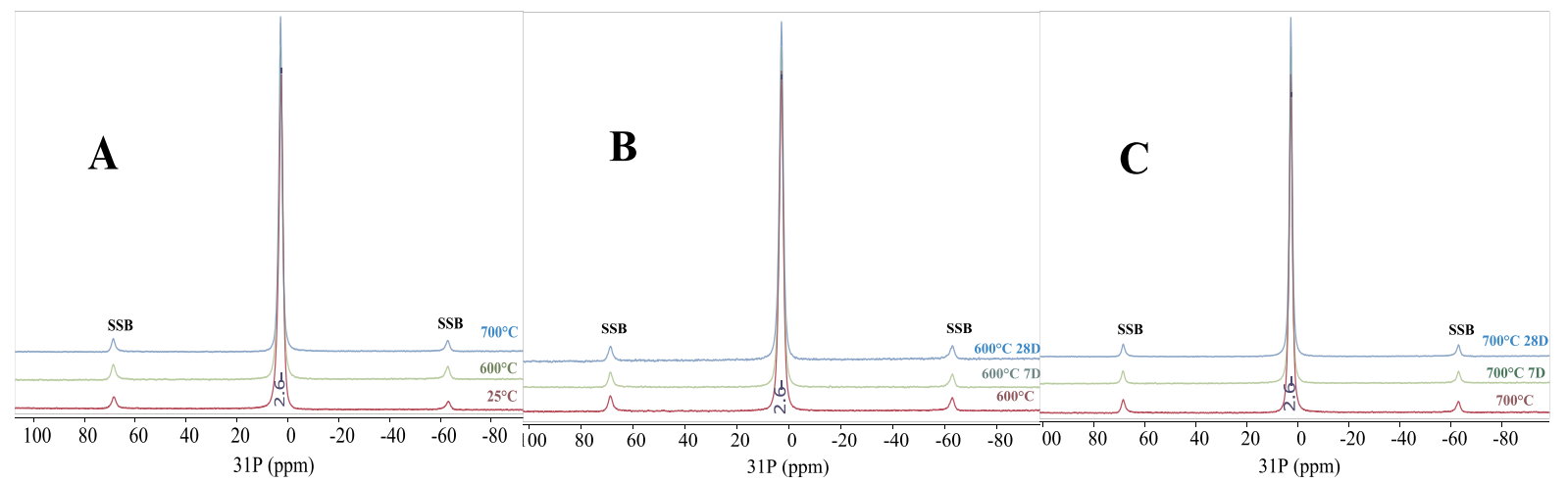

Fig. 5. ${ }^{31} \mathrm{P}$ MAS-NMR of the PWW (A) at different temperatures, (B) $\mathrm{PWW}_{600^{\circ} \mathrm{C}}$ and $\mathrm{AAP}_{600^{\circ} \mathrm{C}}$ at 7 and 28 days, (C) $\mathrm{PWW}_{700^{\circ} \mathrm{C}}$ and $\mathrm{AAP}_{700^{\circ} \mathrm{C}}$ at 7 and 28 days.

$-102 \mathrm{ppm}$ related to $\mathrm{Q}^{1}, \mathrm{Q}^{2}(\mathrm{mAl})$ and $\mathrm{Q}^{4}(\mathrm{mAl})$ with $\mathrm{m}$ between 0 and 4 or else $\mathrm{Q}^{3}(\mathrm{mAl})$ respectively $[42,45,46]$. The reaction of $P W W_{600^{\circ} \mathrm{C}}$ after alkali activation was complexed. The results of ${ }^{27} \mathrm{Si}$ MAS-NMR show that two different type of reaction products can be detected. The first product is the highly crosslinked framework silicate N-A-S-H, with the incorporation of Ca-modified geopolymer gel noted (C, N)-A-S-H that has a 3-D structure characterize with $\mathrm{Q}^{3}$ and $\mathrm{Q}^{4} \mathrm{Si}$ sites $[42,44,47]$. The second is C-S-H/C-(A)-S-H gel has a 2-D chain silicate structure with $\mathrm{Q}^{1}$ and $\mathrm{Q}^{2} \mathrm{Si}$ sites $[45,46]$. The samples show with the increase of the curing time a narrowing of the resonance which explains the increased ordering within the 2 different formed gels.

The ${ }^{29} \mathrm{Si}$-NMR of the $A A P_{700^{\circ} \mathrm{C}}$ at 7 and 28 days are presented in Fig. 4C. The curves show an important shift compared to the unactivated $P W W_{700^{\circ} \mathrm{C}}$. The $A A P_{700^{\circ} \mathrm{C}}$ spectra display new peaks in a new region between -76 and $-93 \mathrm{ppm}$ compared to the unreacted phosphate washing waste demonstrated in Fig. 7.
After alkali activation, the curves present also 3 clear groups. First group with a chemical shift centered at about $-72 \mathrm{ppm}$ suggestion the presence of isolated tetrahedral $\mathrm{Q}^{0}$ within the reaction products. This peak can also refer to the $\mathrm{C}_{2} \mathrm{~S}$ phases. However, according to many authors [42,48-50], after alkali activation, $\mathrm{C}_{2} \mathrm{~S}$ reacts and generates new phase. The second group was at between $-75 \mathrm{ppm}$ and $-85 \mathrm{ppm}$ correspond to $\mathrm{Q}^{1}$ (chain end group) and $\mathrm{Q}^{2}$ (middle chain group) denoted the newly formed phase of $\mathrm{C}-\mathrm{S}-\mathrm{H}[44,51]$. The third group of peaks presented between $-87 \mathrm{ppm}$ and $-97 \mathrm{ppm}$. Based on the data reported in the literature $[39,46,52,53]$ the shift at about $-87 \mathrm{ppm}$ correspond to $\mathrm{Q}^{4}(4 \mathrm{Al})$ and the shift from $-90 \mathrm{ppm}$ to -97 can correspond to $\mathrm{Q}^{3}$ and $\mathrm{Q}^{4}(\mathrm{mAl})$ tetrahedral silica surrounded by 3,2 or 1 alumina units $[39,42,49,54]$. The activation of $P W W_{700^{\circ} \mathrm{C}}$ displays also 2 different types of reactions. The main reaction is the formation of $3 \mathrm{D}$ $\mathrm{N}-\mathrm{A}-\mathrm{S}-\mathrm{H}$ in which $\mathrm{Ca}$ displace $\mathrm{Na}$ ions and leads to the formation of (C, $\mathrm{N})-\mathrm{A}-\mathrm{S}-\mathrm{H}$ gel [52]. The second reaction is the formation of the 
Table 2

${ }^{29} \mathrm{Si},{ }^{27} \mathrm{Al}$ and ${ }^{31} \mathrm{P}$ MAS-NMR of PWW at different temperatures $\left(25^{\circ} \mathrm{C}, 600{ }^{\circ} \mathrm{C}\right.$ and $\left.700{ }^{\circ} \mathrm{C}\right)$.

\begin{tabular}{|c|c|c|c|c|}
\hline & Assignment & $25^{\circ} \mathrm{C}$ & $600^{\circ} \mathrm{C}$ & $700^{\circ} \mathrm{C}$ \\
\hline \multirow[t]{12}{*}{${ }^{29} \mathrm{Si}$} & $\mathrm{Q}^{3}(\mathrm{mAl})$ & Palygorskite -92 , & Palygorskite -91, & - \\
\hline & $\mathrm{Q}^{3}(1 \mathrm{Al})$ & $-97 \mathrm{ppm}$ & $-96 \mathrm{ppm}$ & Phlogopite \\
\hline & $\mathrm{Q}^{4}(2 \mathrm{Al})$ & - & - & $-86 \mathrm{ppm}$ \\
\hline & $\mathrm{Q}^{4}(1 \mathrm{Al})$ & Heulandite-K & Heulandite-K & Heulandite-K \\
\hline & $\mathrm{Q}^{4}(\mathrm{OAl})$ & $-93 \mathrm{ppm}$ & -95 & $-95 \mathrm{ppm}$ \\
\hline & $\mathrm{Q}^{4}(\mathrm{OAl})$ & Heulandite-K & Heulandite-K & Heulandite-K \\
\hline & $\mathrm{Q}^{0}$ & $-101 \mathrm{ppm}$ & -101 & $-10 \mathrm{ppm}$ \\
\hline & & Quartz & Quartz -107 & Quartz \\
\hline & & $-107 \mathrm{ppm}$ & Framework (0Al) & $-107 \mathrm{ppm}$ \\
\hline & & Framework & $-111,-113$ & Framework \\
\hline & & (0Al)-112, -113 & - & (OAl)-112 \\
\hline & & - & & $\mathrm{C}_{2} \mathrm{~S}-71 \mathrm{ppm}$ \\
\hline \multirow[t]{6}{*}{${ }^{27} \mathrm{Al}$} & $\mathrm{Al}_{\text {oct }}$ & Palygorskite & Palygorskite & Phlogopite 2 ppm \\
\hline & $\mathrm{Al}_{\text {tet }}$ & $3 \mathrm{ppm}$ & $3 \mathrm{ppm}$ & - \\
\hline & & Palygorskite & Palygorskite & Heulandite \\
\hline & & $54 \mathrm{ppm}$ & $54 \mathrm{ppm}$ & $56 \mathrm{ppm}$ \\
\hline & & Heulandite & Heulandite & \\
\hline & & $58 \mathrm{ppm}$ & $56 \mathrm{ppm}$ & \\
\hline \multirow[t]{3}{*}{${ }^{31} \mathrm{P}$} & & Carbonate & Carbonate & Carbonate \\
\hline & & Fluorapatite & Fluorapatite & Fluorapatite \\
\hline & & $2.6 \mathrm{ppm}$ & $2.6 \mathrm{ppm}$ & $2.6 \mathrm{ppm}$ \\
\hline
\end{tabular}

\section{C-S-H/C-(A)-S-H gel.}

\section{5. ${ }^{27}$ Al-NMR spectroscopy of AAP}

The ${ }^{27} \mathrm{Al}$ NMR provided additional information about the environment of the $\mathrm{Al}$ nuclei in the new formed materials. The spectra of the $P W W$ uncalcined and calcined at $600{ }^{\circ} \mathrm{C}$ and $700{ }^{\circ} \mathrm{C}$ presented in Fig. $3 \mathrm{~A}$, show 2 environments correspond to the $\mathrm{Al}(\mathrm{IV})$ and $\mathrm{Al}(\mathrm{VI})$. After calcination the curves exhibit a decrease of the 6-coordinated $\mathrm{Al}$ and an increase of the 4-coordinated $\mathrm{Al}$ and this was explained by the start of dihydroxylation of the palygorskite [43]. The 4-coordinated Al corresponds to the heulandite and also to the palygosrkite present in the powder at $25^{\circ} \mathrm{C}$ and $600^{\circ} \mathrm{C}$. At $700{ }^{\circ} \mathrm{C}$ the 2 environments correspond to the aluminum present in the heulandite and the phlogopite phases.

The ${ }^{27} \mathrm{Al}$ MAS-NMR spectra of the $A A P_{600^{\circ} \mathrm{C}}$ and $A A P_{700^{\circ} \mathrm{C}}$ are presented in Fig. $3 \mathrm{~B}$ and $3 \mathrm{C}$ respectively. The $A A P_{600^{\circ} \mathrm{C}}^{27} \mathrm{Al}$ MAS-NMR spectrum reveals the presence of both tetrahedrally and octahedrally coordinated aluminum. The 6-coordinated $\mathrm{Al}$ appeared to be unaffected by the alkali activation. It can be seen from the data in Table 3 that the intensity of those peaks did not show also a big difference from 7 to 28 days. In contrast, the $A A P_{700^{\circ} \mathrm{C}}$ presents a tetrahedrally coordinated aluminum with highest intensity. While the octahedrally aluminum makes a chemical shift to $3.6 \mathrm{ppm}$ and $1.77 \mathrm{ppm}$ at 7 and 28 days respectively and the intensity of those peaks dropped clearly compared to the $P W W_{700^{\circ} \mathrm{C}}$ as Table 3 shows.

The difference of the intensity of the two environments of $\mathrm{Al}$ can be explained differently. First the presence of $\mathrm{Al}(\mathrm{VI})$ in the $A A P_{600^{\circ} \mathrm{C}}$ with the high intensity could be related to the low geopolymerization degree in the samples. Secondly the availability of Al (VI) from the phases present in the $P W W_{600}{ }^{\circ}$ is limited by the nature of these phases. In this case the palygorskite which present the octahedrally environment of aluminum is the phase that can show a limited or negligible contribution to the activation reaction. However, based on the results of the XRD in Fig. 2B and according to Wango et al. [55], at higher alkali medium the palygoskrite is consumed and presents other new phases. The third hypothesis is that the Al(VI) are forming individual phases [56].

The ${ }^{27} \mathrm{Al}$ MAS-NMR spectra of the $A A P_{700^{\circ} \mathrm{C}}$ shows that most of the aluminum is tetrahedrally coordinated. The curves present the transformation of $\mathrm{Al}(\mathrm{VI})$ to $\mathrm{Al}(\mathrm{IV})$ which indicates that aluminum is incorporated in the new formed phases. The curves show also a peak with low intensity and sharper shape at around $3.6 \mathrm{ppm}$ and $1.7 \mathrm{ppm}$ at 7 and 28 days respectively. The attribution of those peaks is not clearly determined in the literature, but it can be assigned to the hydrated crystalline phases [51,57] or is attributed to $\mathrm{Al}(\mathrm{VI})$ linked to $\mathrm{Mg}$ in a spinel-type structure $[47,58]$.

The ${ }^{27} \mathrm{Al}$ MAS-NMR spectra of each $A A P_{600^{\circ} \mathrm{C}}$ and $A A P_{700^{\circ} \mathrm{C}}$ cured at 7 and 28-days exhibit high resonance from 30 to $70 \mathrm{ppm}$ and centered at approximately $55 \mathrm{ppm}$, which assigned to four-fold coordinated $\mathrm{Al}$ namely q4(4Si) in a significant disordered tetrahedral environment [39, 42,59]. In this case it is the formed amorphous N-A-S-H/(N, C)-A-S-H gel.

The ${ }^{31} \mathrm{P}$ MAS-NMR spectra presented in Fig. 5B and 5C show the phosphorus environment in the fluorapatite. It is clearly that the environment did not present a chemical shift after alkali activation. These results indicate that the fluorapatite did not react after alkali activation [14] and confirm the results of the XRD.

\subsection{Attenuated total reflectance Fourier transform infrared spectroscopy (ATR-FTIR)}

ATR-FTIR spectra collected of the $P W W$ calcined at $600{ }^{\circ} \mathrm{C}$ and $700{ }^{\circ} \mathrm{C}$ and activated powders cured at 7 and 28 days are presented in Fig. 8A. As discussed in the previous work [43], the FTIR spectra show 2

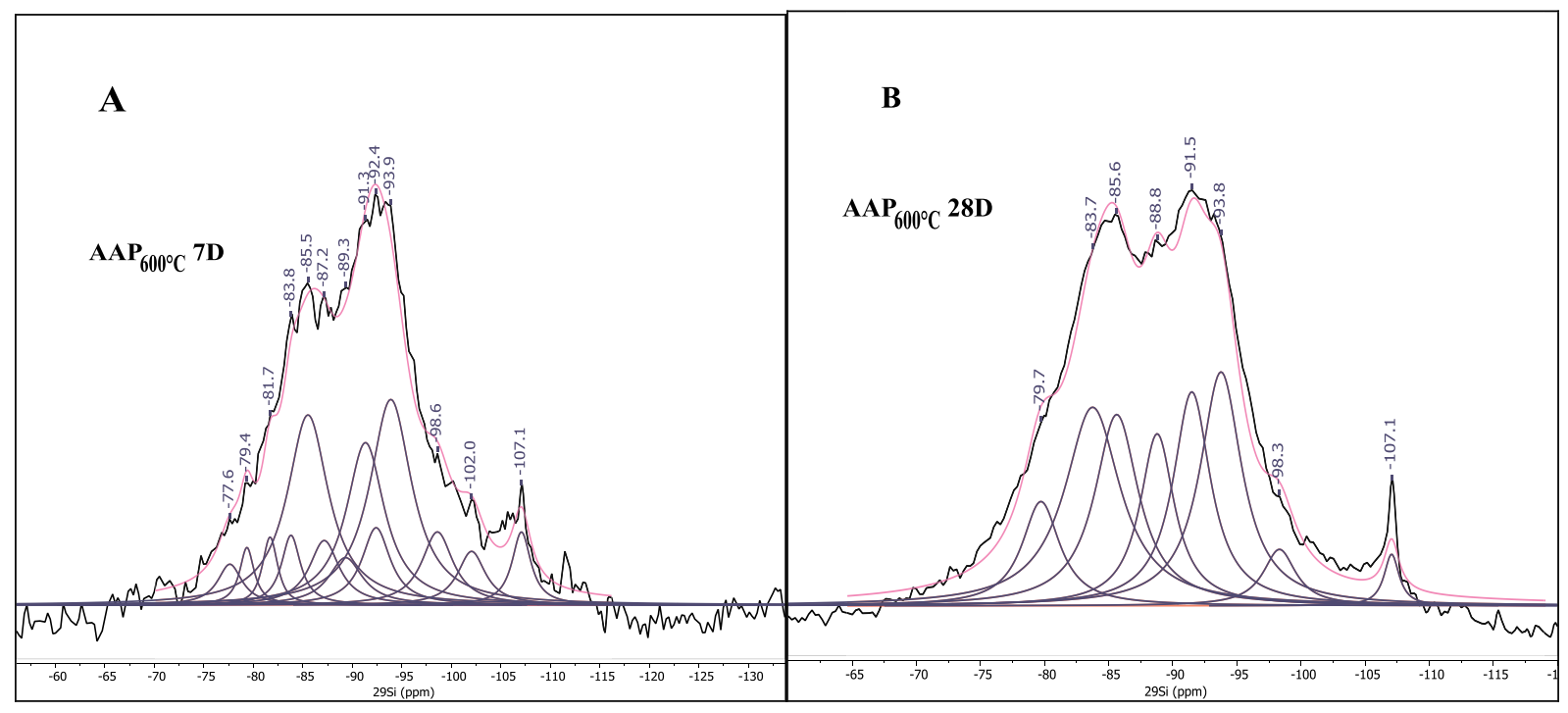

Fig. 6. Deconvolution curves of $\mathrm{AAP}_{600^{\circ} \mathrm{C}}$ at A) 7 and B) 28 days. 


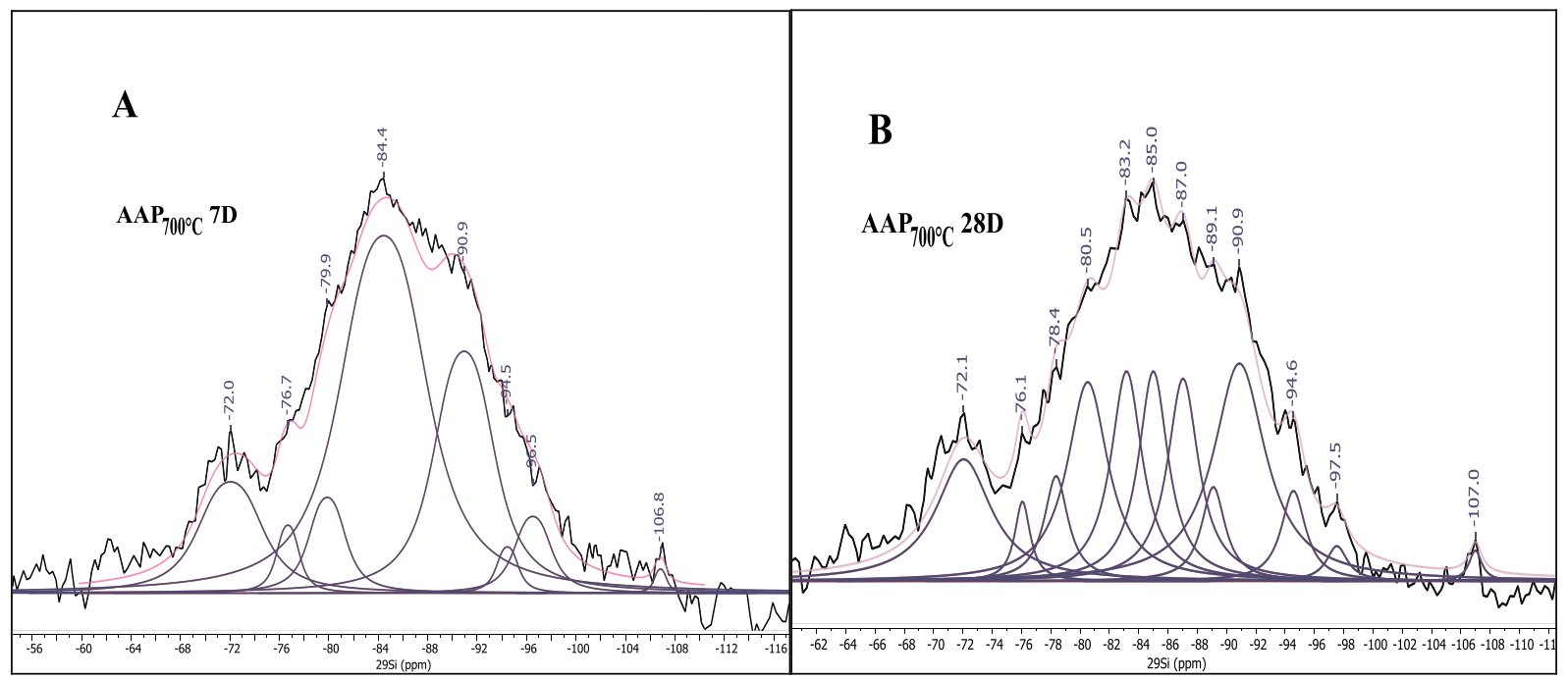

Fig. 7. Deconvolution curves of $\mathrm{AAP}_{700^{\circ} \mathrm{C}}$ at A) 7 and B) 28 days.

Table 3

The chemical shifts and area of the $\mathrm{Al}$ peaks.

\begin{tabular}{|c|c|c|c|c|c|c|c|c|c|c|c|c|}
\hline & \multicolumn{6}{|l|}{$600^{\circ} \mathrm{C}$} & \multicolumn{6}{|l|}{$700^{\circ} \mathrm{C}$} \\
\hline & \multicolumn{2}{|c|}{ No activated } & \multicolumn{2}{|l|}{ 7days } & \multicolumn{2}{|l|}{28 days } & \multicolumn{2}{|c|}{ No activated } & \multicolumn{2}{|l|}{7 days } & \multicolumn{2}{|l|}{28 days } \\
\hline & Shift ppm & Area $\%$ & Shift ppm & Area $\%$ & Shift ppm & Area $\%$ & Shift ppm & Area $\%$ & Shift ppm & Area $\%$ & Shift ppm & Area $\%$ \\
\hline $\mathbf{A l}_{\mathrm{OCT}}$ & 2.7 & 44.39 & 3.4 & 37.19 & 3.4 & 38.94 & 2.6 & 38.9 & 3.6 & 13.9 & 1.77 & 12.4 \\
\hline $\mathrm{Al}_{\mathrm{TET}}$ & 55.7 & 54.59 & 55.3 & 62.30 & 55.2 & 59.48 & 55.5 & 60.4 & 56.2 & 84.7 & 55.2 & 86.3 \\
\hline
\end{tabular}

sensitive zones to the calcination, from 400 to $800 \mathrm{~cm}^{-1}$ and from 800 to $1400 \mathrm{~cm}^{-1}$. After calcination the curves show the disappearance of the bands at $3611 \mathrm{~cm}^{-1}, 3544 \mathrm{~cm}^{-1}$ correspond to the stretching vibration mode of the $[\mathrm{OH}]$ group. Bending vibration at $1636 \mathrm{~cm}^{-1}$ correspond to the chemically bound water. The carbonate fluorapatite was characterized by the band at $466,567,576,604,944$ and $1050 \mathrm{~cm}^{-1}$ correspond to the $\mathrm{PO}_{4}^{3-}$ functional group, and $1448 \mathrm{~cm}^{-1}$ correspond to the $\mathrm{CO}_{3}^{2-}$ functional group. The bands of $\mathrm{PO}_{4}^{3-}$ persist after calcination with a small shift. The carbonate group disappears totally at $700^{\circ} \mathrm{C}$. The bands at 713, 875 and $1431 \mathrm{~cm}^{-1}$ correspond of the $\mathrm{CO}_{3}^{2-}$ present in the calcite phases. These bands decrease at $600{ }^{\circ} \mathrm{C}$ and $700{ }^{\circ} \mathrm{C}$. The palygorskite was defined by the bands at 520, 911, 987 and $1033 \mathrm{~cm}^{-1}$ correspond to $\mathrm{Si}-\mathrm{O}-\mathrm{Si}, \mathrm{Al}-\mathrm{OH}-\mathrm{Al}, \mathrm{Si}-\mathrm{O}-\mathrm{Mg}$ and $\mathrm{Si}-\mathrm{O}-\mathrm{Si}$ respectively. These bands vanish totally at $700^{\circ} \mathrm{C}$. The heulandite was characterized by the bands at $1022 \mathrm{~cm}^{-1}$ of the $\mathrm{Si}-\mathrm{O}$-T group where $\mathrm{T}$ : $\mathrm{Si}$ or Al. This band shift to higher wavenumber to 1026 and $1031 \mathrm{~cm}^{-1}$ at $600{ }^{\circ} \mathrm{C}$ and $700{ }^{\circ} \mathrm{C}$ respectively. The XRD shows the appearance of new phases at $700{ }^{\circ} \mathrm{C}$ as the phlogopite characterized by the band at 980 and $1060 \mathrm{~cm}^{-1}$ for the $\mathrm{Si}-\mathrm{O}$ functional group, and $\mathrm{C}_{2} \mathrm{~S}$ defined by the bands at $512,880 \mathrm{~cm}^{-1}$ of the $\mathrm{Si}-\mathrm{O}$ functional group and at 991 and $845 \mathrm{~cm}^{-1}$ for the $\mathrm{Si}-\mathrm{O}-\mathrm{Ca}$.

Fig. 8B shows the infrared spectra of the $P W W_{600}{ }^{\circ} \mathrm{C}$ and the $A A P_{600} \mathrm{C}$ cured for 7 and 28 days. The curves display a significant difference compared to the starting powder in the 2 sensitive zones $\left(400-800 \mathrm{~cm}^{-1}\right)$ and $\left(800-1200 \mathrm{~cm}^{-1}\right)$. With the increase of the curing time from 7 to 28 days these zones did not made significant change. The main broad band at around $995 \mathrm{~cm}^{-1}$ is associated with the asymmetric stretching vibration mode of $\mathrm{Si}-\mathrm{O}-\mathrm{T}$ where $\mathrm{T}$ : $\mathrm{Si}$ or $\mathrm{Al}$. This band is typical to the band in the N-A-S-H gel $[45,60]$. The shift of the band to the lower frequency from the originally at about $1026 \mathrm{~cm}^{-1}$ to $995 \mathrm{~cm}^{-1}$ imply a chemical change in the matrix can be explained by the dissolution of the reactive phases in the $P W W_{600^{\circ} \mathrm{C}}$ and their contribution in the formation of the geopolymeric phase N-A-S-H, also by the incorporation of the $\mathrm{Al}$ and $\mathrm{Ca}$ cation in the formed gel $[40,61]$. The two curves show also a vibrational band at about $875 \mathrm{~cm}^{-1}$ and $1430 \mathrm{~cm}^{-1}$ corresponding to the bending and stretching vibration of carbonate groups which confirm the XRD and the DSC-TG results [13]. A small band at $1691 \mathrm{~cm}^{-1}$ correspond to the bending vibration modes of $\mathrm{H}-\mathrm{OH}$.

The spectra presented also in Fig. $8 \mathrm{~B}$ show the samples $P W W_{700^{\circ} \mathrm{C}}$ and $A A P_{700^{\circ} \mathrm{C}}$ cured at 7 and 28 days. The main band at $1031 \mathrm{~cm}^{-1}$ presented in the inactivated $P W W_{700^{\circ} \mathrm{C}}$ shift towards further lower wavenumber $968 \mathrm{~cm}^{-1}$ compared to the $A A P_{600^{\circ} \mathrm{C}}$. This band is assigned to the $\mathrm{Si}-\mathrm{O}-\mathrm{T}$ ( $\mathrm{Si}$ or $\mathrm{Al}$ ), this might indicate the incorporation of more $\mathrm{Al}$ in the formed product and confirm the MAS-NMR results. The curves display also a small asymmetric stretching band at about $1446 \mathrm{~cm}^{-1}$ present the carbonate groups. This band can be displayed from some superficial carbonation of the samples during curing but probably by physical mechanisms rather than chemical reaction [62] as no growth in crystalline carbonate phases was observed by XRD. A band at about $1676 \mathrm{~cm}^{-1}$ correspond to the bending vibration modes of $\mathrm{H}-\mathrm{OH}$. The samples show a shoulder at $874 \mathrm{~cm}^{-1}$ and $879 \mathrm{~cm}^{-1}$ from 7 to 28 days are associated with the asymmetric stretch of $\mathrm{AlO}_{4}^{-}$groups in $\mathrm{Al}-\mathrm{O}-\mathrm{Si}$ $[42,62]$. bending vibration of $\mathrm{Si}-\mathrm{O}-\mathrm{Si}$ and $\mathrm{O}-\mathrm{Si}-\mathrm{O}$ in the $440 \mathrm{~cm}^{-1}$ region are presented in the 2 curves [60].

Electron microscope scanning and energy dispersive spectroscopy (SEM-EDS).

Electron microscope scanning was used to examine the microscopic effect of the alkali activation of the $P W W_{600^{\circ} \mathrm{C}}$ and $P W W_{700^{\circ} \mathrm{C}}$ at 28 days, and the EDS analysis was conducted on the sample and the results are summarized in Table 4. Different microstructures developed as a consequence of the activation of the 2 powders with the alkaline solution. Fig. 9A, B, shows a representative scanning electron microscope of the $A A P_{600} \mathrm{C}$ at 28 days. When the $P W W_{600^{\circ} \mathrm{C}}$ is activated by the alkali solution, an aluminosilicates gel was formed with 3D network (N-A-S$\mathrm{H}),(\mathrm{N}, \mathrm{C})-\mathrm{A}-\mathrm{S}-\mathrm{H}$ and 2D (C-S-H) while it was difficult to separate between these 2 phases. At 28 days the $A A P_{700^{\circ} \mathrm{C}}$ sample Fig. $9 \mathrm{C}, \mathrm{D}$ reported significantly more formed phases than the $A A P_{600^{\circ} \mathrm{C}}$. It displays the 

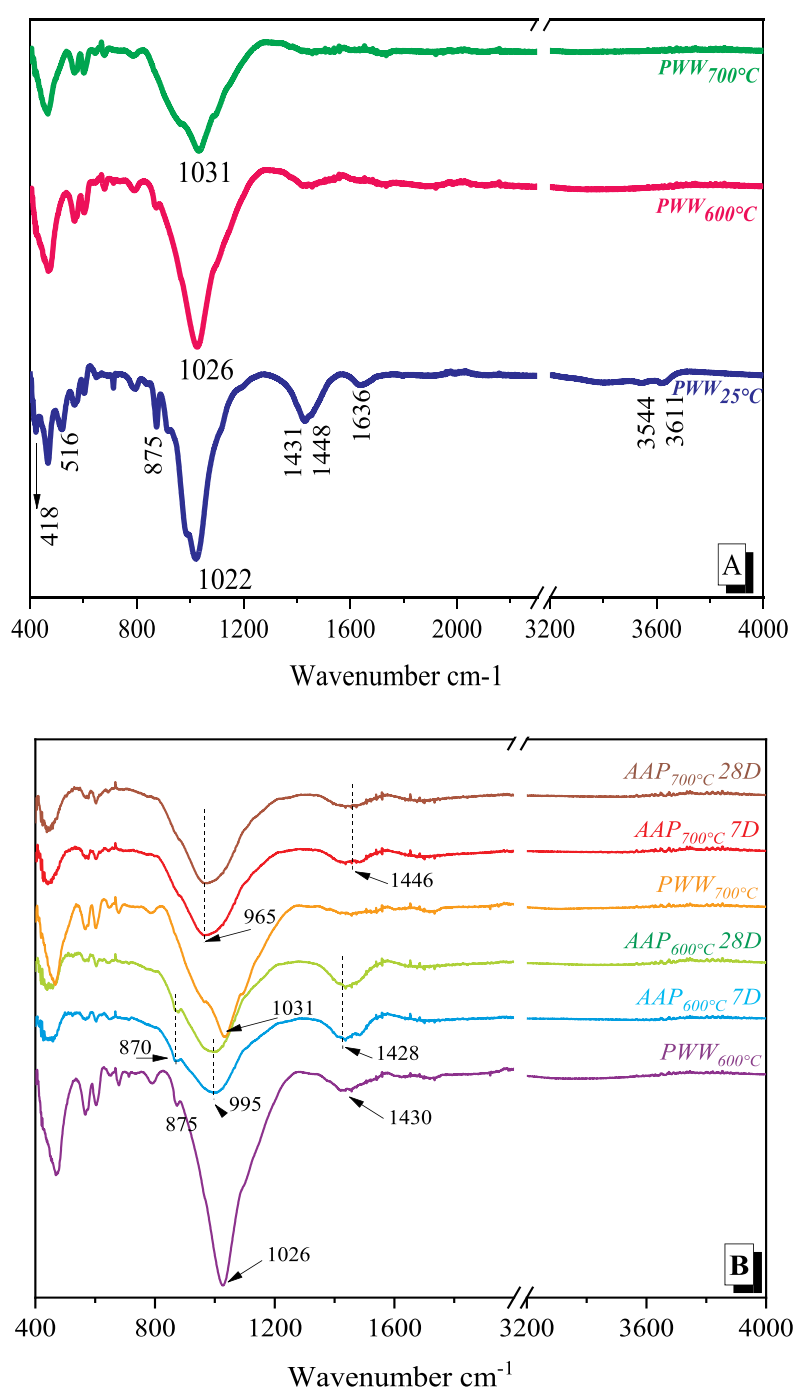

Fig. 8. FTIR of the (A) $\mathrm{PWW}, \mathrm{PWW}_{600^{\circ} \mathrm{C}}$ and $\mathrm{PWW}_{700^{\circ} \mathrm{C}}$ (B) $\mathrm{PWW}_{600^{\circ} \mathrm{C}}$ and $\mathrm{AAP}_{600^{\circ} \mathrm{C}}$ at 7 and 28 days $\mathrm{PWW}_{700^{\circ} \mathrm{C}}$ and $\mathrm{AAP}_{700^{\circ} \mathrm{C}}$ at 7 and 28 days.

presence of the 3D network (N-A-S-H), (N,C)-A-S-H and 2D (C-S-H) and also a small particles of zeolite that was not spread with high quantities in the formed sample.

From Table 4, it was clearly shown that the elemental composition of $A A P_{600}{ }^{\circ} \mathrm{C}$ and $A A P_{700^{\circ} \mathrm{C}}$ in zone1 and zone2 respectively, was dominated by silicon, calcium, sodium and aluminum. The $A A P_{700^{\circ} \mathrm{C}}$ exhibit also the $\mathrm{C}-\mathrm{S}-\mathrm{H}$ phase as a separate phase following the hydration of the $\mathrm{C}_{2} \mathrm{~S}$ [48].

The zones 3 and zones $1+3$ of $A A P_{600}{ }^{\circ} \mathrm{C}$ and $A A P_{700^{\circ} \mathrm{C}}$ respectively show the particles of fluorapatite that stayed no reacted after activation which confirm the XRD and MAS-NMR results. Small amount of zeolites was displayed in the SEM-EDS analysis that did not appear in the XRD diffractometer.

\section{Discussion}

Exploring the obtained results XRD, MAS-NMR, FTIR, SEM-EDS and DSC-TG [13], analysis of the $A A P_{600^{\circ} \mathrm{C}}$ and $A A P_{700^{\circ} \mathrm{C}}$, it was clear that the alkali activation of the 2 precursors leads to the formation of new phases which affect the compressive strength of the obtained materials.

The present study was designed to determine first the effect of the calcination process on the mineralogical composition of the PWW. As described in previous work [43] the calcination affect significantly the phases of the $P W W$. As one of interesting finding in this study is the role of $\mathrm{Al}$ present in the $P W W_{600^{\circ} \mathrm{C}}$ and $P W W_{700^{\circ} \mathrm{C}}$ was different. The two precursors present a 4-coordinated $\mathrm{Al}$ and 6-coordinated $\mathrm{Al}$ with different population but the results provide that the 6-coordinated $\mathrm{Al}$ did not react with same way. After activation, the $A A P_{700^{\circ} \mathrm{C}}$ was characterized with 4-coordinated $\mathrm{Al}$ at about $55 \mathrm{ppm}$ with an important intensity after the consumption of the most of 6-coordinated Al. This environment indicating the higher silicon surrounded $\mathrm{Al}, \mathrm{q} 4(4 \mathrm{Si})$ environment [39, 49,56], means that one aluminum is surrounded by for silicon. This state describes the position of $\mathrm{Al}$ within the $3 \mathrm{D}$ network. However, the population of the 6-coordinated $\mathrm{Al}$ for $A A P_{600^{\circ} \mathrm{C}}$ was higher compared to the $A A P_{700^{\circ} \mathrm{C}}$ and did not show a significant change from 7 to 28 days. As aluminum is one of the elements that plays an important role in the alkali activated materials. The difference of compressive strength presented in Fig. 1 can be first explained by the role of $\mathrm{Al}$ in the 2 powders following the calcination and the activation process. According to Chao, Roosz and Duxon [57,63-65] aluminum and the rate of its release throughout the reaction cause the higher compressive strength of the obtained materials.

The difference of the compressive strength and its variation from 7 to 28 days for the 2 samples may be explained by the fact that also the amount of the reactive calcium present in the 2 precursors was not the same. The Ca cation is present in different phases (Anhydrite, Calcite and Heulandite in $P W W_{600}{ }^{\circ} \mathrm{C}$ and Anhydrite, Calcite, Heulandite and $\mathrm{C}_{2} \mathrm{~S}$ in $P W W_{700^{\circ}} \mathrm{C}$. The difference of those phases from $600{ }^{\circ} \mathrm{C}$ to $700^{\circ} \mathrm{C}$ were their reactivity. The heulandite and calcite were altered after calcination with decomposition of heulandite and decarbonation of calcite. Those phenomena were significantly important at $700^{\circ} \mathrm{C}$ than $600^{\circ} \mathrm{C}$. Based on the literature $[42,54,63]$, the calcium has a positive effect on the compressive strength and this behavior depends on the amount and the form in which it is present. The Ca cation in this case plays two functions; replace $\mathrm{Na}$ cation by ion exchange like the phenomena presented in the clay or zeolite $[40,49,66]$ for the N-A-S-H/(N,C)-A-S-H or forming other phases like $\mathrm{C}-\mathrm{S}-\mathrm{H}$ or $\mathrm{C}-(\mathrm{A})-\mathrm{S}-\mathrm{H}$. The presence of the different phases caused by the reaction of Ca cation in alkali medium can explain the evolution of the compressive strength of the 2 samples [67].

Based on the FTIR analysis the main band at $995 \mathrm{~cm}^{-1}$ of $A A P_{600^{\circ} \mathrm{C}}$ was at higher wavenumber compared to the $A A P_{700^{\circ}} \mathrm{C}$ which appear at $965 \mathrm{~cm}^{-1}$. This band displays the $\mathrm{Si}-\mathrm{O}-\mathrm{T}$ where $\mathrm{T}$ is a tetrahedrally coordinated cation and the incorporation of a large $\mathrm{T}$ : $\mathrm{Al}$ and Ca will shift the band toward lower wavenumber [40]. These results confirm that more $\mathrm{Al}$ and $\mathrm{Ca}$ are present in the formed gel of $A A P_{700^{\circ} \mathrm{C}}$ than in the $A A P_{600^{\circ} \mathrm{C}}[60,66,68]$. Making a relation between the results, the increase of reactive calcium in the powder leads to the increase of the incorporation of $\mathrm{Al}$ within the new phases $[45,46]$.

Table 4

The average elemental compositions of the different zones presented in Fig. 9.

\begin{tabular}{|c|c|c|c|c|c|c|c|}
\hline & ${ }_{\text {Wt. } \%}$ Zone & Silicon (Si) & Calcium(Ca) & Sodium(Na) & Aluminum(Al) & Oxygen $(\mathrm{O})$ & Phosphorus(P) \\
\hline \multirow[t]{3}{*}{$A A P_{600^{\circ} \mathrm{C}}$} & Zone1 & 20 & 12.42 & 13 & 2.31 & 42 & - \\
\hline & Zone2 & 60 & - & - & - & 37 & - \\
\hline & Zone3 & 6 & 34.2 & 5.8 & - & 35.8 & 10.2 \\
\hline \multirow{5}{*}{$A A P_{700^{\circ} \mathrm{C}}$} & Zone $1+3$ & 4.2 & 55 & 2.5 & - & 25.5 & 5.65 \\
\hline & Zone2 & 19.8 & 12.8 & 10.7 & 2.9 & 43.5 & - \\
\hline & Zone4 & 35 & 2.89 & 3.6 & 6.8 & 45.2 & - \\
\hline & Zone5 & 61.3 & - & - & - & 35 & - \\
\hline & Zone6 & 33.07 & 38.4 & 2.03 & - & 19.9 & - \\
\hline
\end{tabular}



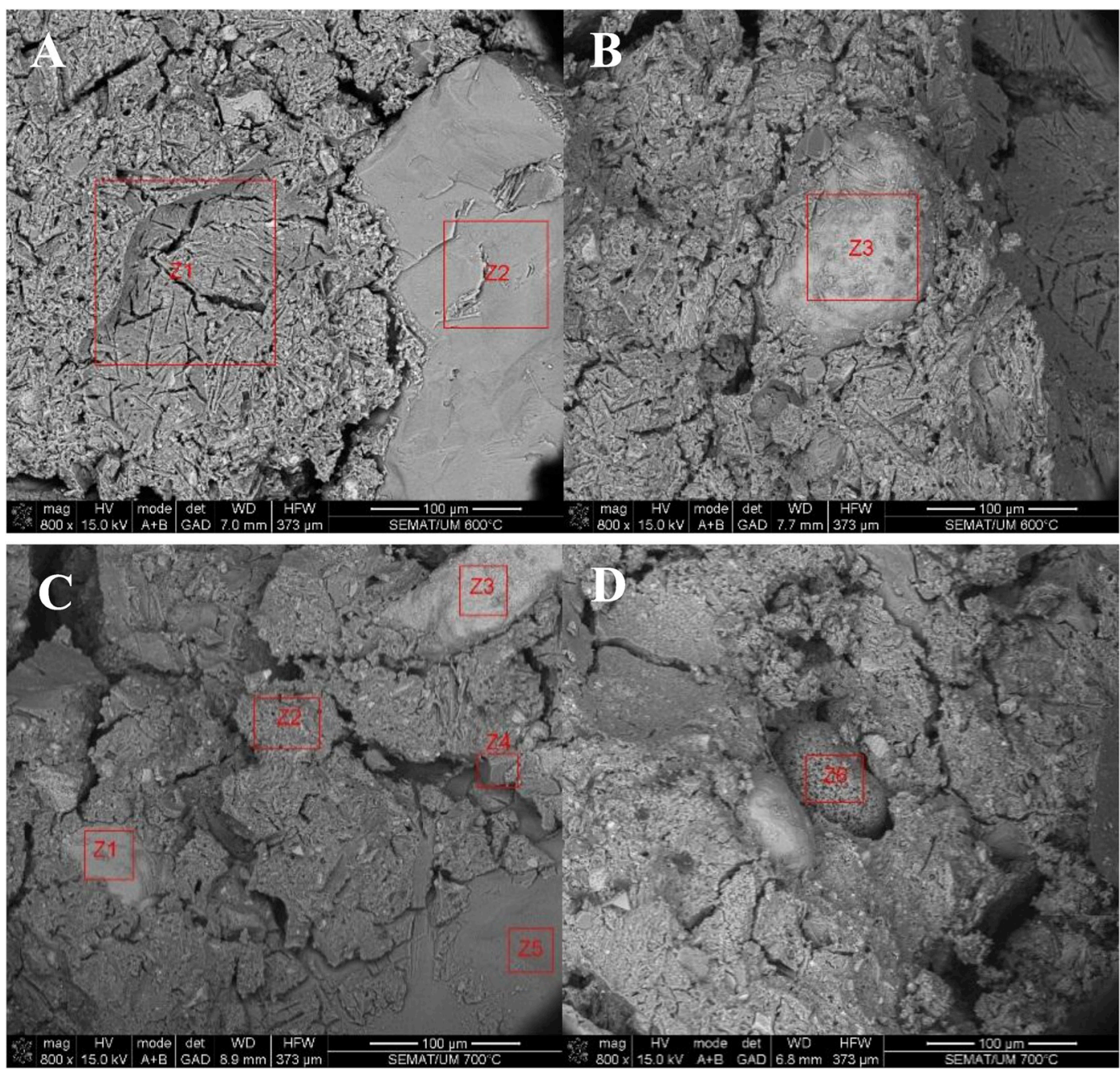

Fig. 9. SEM observation of the $\mathrm{AAP}_{600^{\circ} \mathrm{C}}(\mathrm{A}, \mathrm{B})$ and $\mathrm{AAP}_{700^{\circ} \mathrm{C}}(\mathrm{C}, \mathrm{D})$ at 28 days.

This system can be described as follow. The alkali activation of $P W W_{600}{ }^{\circ} \mathrm{C}$ and $P W W_{700}{ }^{\circ} \mathrm{C}$ conduct to dissolution of different sources of silicon and aluminum (heulandite, palygorskite and phlogopite) and other sources of calcium (anhydride, calcite and $\mathrm{C}_{2} \mathrm{~S}$ ) to give different species $\left(\mathrm{SiO}_{2}(\mathrm{OH})_{2}^{2-}\right)$ or $\mathrm{SiO}(\mathrm{OH})_{3}^{-}, \mathrm{Al}(\mathrm{OH})_{4}^{-}, \mathrm{Ca}^{2+}, \mathrm{SO}_{4}^{2-} \quad[61,67]$. Interaction between all these species generate two types of reaction. the precipitation of N-A-S-H gel or the C-S-H gel. Furthermore, the study displays the presence of other ions from the dissolution as the $\mathrm{Mg}^{2+}$, $\mathrm{K}^{+}$and $\mathrm{Na}^{2+}$ are incorporated in the formed gels.

\section{Conclusion}

The aim of this study is to investigate the reactivity and reaction products of alkali-activated

phosphate washing waste calcined at two different temperatures 600 and $700{ }^{\circ} \mathrm{C}$. The results show that:

- The calcination temperature has an important effect on the reactivity of the phosphate washing waste PWW.

- The alkali activation of the $P W W_{600^{\circ} \mathrm{C}}$ and $P W W_{700^{\circ} \mathrm{C}}$, generate two types of reactions confirmed by the MAS-NMR and SEM-EDS analysis which are the formation of the 3D network N-A-S-H/(C,N)-A-S-H gel and the C-S-H, C-(A)-S-H gel.

- The activation demonstrates the consumption of all the aluminosilicate phases (Heulandite, palygorskite and phlogopite) and calcium from anhydrite, $\mathrm{C}_{2} \mathrm{~S}$ and calcite. It shows also that the fluorapatite and quartz did not react after activation.

- The role of active calcium and aluminum present in the 2 powders can explain the difference of the compressive strength of the two mortars.

\section{Acknowledgements}

The authors would like to acknowledge the both universities for their support and the Gafsa Phosphate Company "CPG Tunisia" for providing us the phosphate washing waste sample.

\section{References}

[1] B.G. Lottermoser, Mine Wastes: Characterization, Treatment and Environmental Impacts, third ed. ed, 2010.

[2] J.A. Ober, Mineral Commodity Summaries 2018, Mineral Commodity SummariesReston, VA, 2018, p. 204

[3] B.L. Sørensen, O.L. Dall, K. Habib, Environmental and resource implications of phosphorus recovery from waste activated sludge, Waste Manag. 45 (2015) 391-399.

[4] G. Steiner, B. Geissler, I. Watson, M.C. Mew, Efficiency developments in phosphate rock mining over the last three decades, Resources, Conserv. Recycl. 105 (2015) $235-245$.

[5] R. Hakkou, M. Benzaazoua, B. Bussière, Valorization of phosphate waste rocks and sludge from the Moroccan phosphate mines: challenges and perspectives, Procedia Engineering 138 (2016) 110-118.

[6] S. Jellali, M.A. Wahab, M. Anane, K. Riahi, L. Bousselmi, Phosphate mine wastes reuse for phosphorus removal from aqueous solutions under dynamic conditions, J. Hazard Mater. 184 (2010) 226-233. 
[7] M.P.S. Krekeler, J. Morton, J. Lepp, C.M. Tselepis, M. Samsonov, L.E. Kearns, Mineralogical and geochemical investigation of clay-rich mine tailings from a closed phosphate mine, Bartow Florida.USA.Environ. Geol. 55 (2007) 123-147.

[8] R. Chraiti, M. Raddaoui, A. Hafiane, Effluent water quality at phosphate mines in M'dhilla, Tunisia and its potential environmental effects, Mine Water Environ. 35 (2016) 462-468.

[9] P. Zhang, Comprehensive recovery and sustainable development of phosphate resources, Procedia Engineering 83 (2014) 37-51.

[10] A. Mekki, A. Awali, F. Aloui, S. Loukil, S. Sayadi, Characterization and toxicity assessment of wastewater from rock phosphate processing in Tunisia, Mine Water Environ. 36 (2016) 502-507.

[11] T.E.G. Minpeng Chena, A half-century of global phosphorus flows, stocks, production, consumption, recycling, and environmental impacts, Glob. Environ. Chang. 36 (2016) 139-152.

[12] R. Dabbebi, S. Baklouti, J.L. Barroso de Aguiar, F. Pacheco-Torgal, B. Samet, Investigations of geopolymeric mixtures based on phosphate washing waste, Sci. Technol. Mater. 30 (2018) 1-5.

[13] R. Dabbebi, J.L. Barroso de Aguiar, A. Camões, B. Samet, S. Baklouti, Effect of the calcinations temperatures of phosphate washing waste on the structural and mechanical properties of geopolymeric mortar, Constr. Build. Mater. 185 (2018) 489-498.

[14] S. Moukannaa, M. Loutou, M. Benzaazoua, L. Vitola, J. Alami, R. Hakkou, Recycling of phosphate mine tailings for the production of geopolymers, J. Clean. Prod. 185 (2018) 891-903.

[15] S. Moukannaa, A. Nazari, A. Bagheri, M. Loutou, J.G. Sanjayan, R. Hakkou, Alkaline fused phosphate mine tailings for geopolymer mortar synthesis: thermal stability, mechanical and microstructural properties, J. Non-Cryst. Solids 511 (2019) 76-85.

[16] Q. Chen, Q. Zhang, A. Fourie, C. Xin, Utilization of phosphogypsum and phosphate tailings for cemented paste backfill, J. Environ. Manag. 201 (2017) 19-27.

[17] N. Katamine, Phosphate waste in mixtures to improve their deformation, J. Transport. Eng. 126 (2000) 382-389.

[18] K. Zheng, J. Zhou, M. Gbozee, Influences of phosphate tailings on hydration and properties of Portland cement, Constr. Build. Mater. 98 (2015) 593-601.

[19] M. Loutou, Y. Taha, M. Benzaazoua, Y. Daafi, R. Hakkou, Valorization of clay byproduct from moroccan phosphate mines for the production of fired bricks, J. Clean. Prod. 229 (2019) 169-179.

[20] J. Muliawan, S. Astutiningsih, Preparation and characterization of phosphatesludge kaolin mixture for ceramics bricks, Int. J.Technol. 9 (2018) 317.

[21] M. Khemakhem, S. Khemakhem, S. Ayedi, R.B. Amar, Study of ceramic ultrafiltration membrane support based on phosphate industry subproduct: application for the cuttlefish conditioning effluents treatment, Ceram. Int. 37 (2011) 3617-3625.

[22] M. Khemakhem, S. Khemakhem, S. Ayedi, M. Cretin, R. Ben Amar, Development of an asymmetric ultrafiltration membrane based on phosphates industry subproducts, Ceram. Int. 41 (2015) 10343-10348.

[23] M. Chen, T.E. Graedel, The potential for mining trace elements from phosphate rock, J. Clean. Prod. 91 (2015) 337-346.

[24] S. Marzougui, A. Sdiri, F. Rekhiss, Heavy metals' mobility from phosphate washing effluents discharged in the Gafsa area (southwestern Tunisia), Arabian.J. Geosci. (2016).

[25] M.N. Rashed, A.R. Mohamed, M.A. Awadallah, Chemically activated phosphate slime as adsorbent for heavy metals removal from polluted water, Int. J. Environ. Waste Manag. 16 (2015) 145-165.

[26] M. Wu, Y. Zhang, Y. Ji, G. Liu, C. Liu, W. She, W. Sun, Reducing environmental impacts and carbon emissions: study of effects of superfine cement particles on blended cement containing high volume mineral admixtures, J. Clean. Prod. 196 (2018) 358-369.

[27] L.K. Turner, F.G. Collins, Carbon dioxide equivalent (CO2-e) emissions: a comparison between geopolymer and OPC cement concrete, Constr. Build. Mater. 43 (2013) 125-130.

[28] C. Dupuy, J. Havette, A. Gharzouni, N. Texier-Mandoki, X. Bourbon, S. Rossignol, Metakaolin-based geopolymer: formation of new phases influencing the setting time with the use of additives, Constr. Build. Mater. 200 (2019) 272-281.

[29] Z. Li, S. Zhang, Y. Zuo, W. Chen, G. Ye, Chemical deformation of metakaolin based geopolymer, Cement Concr. Res. 120 (2019) 108-118.

[30] A. Matsuda, I. Maruyama, A. Meawad, S. Pareek, Y. Araki, Reaction, phases, and microstructure of fly ash-based alkali-activated materials, J. Adv. Concr. Technol. 17 (2019) 93-101.

[31] T. Luukkonen, Z. Abdollahnejad, J. Yliniemi, P. Kinnunen, M. Illikainen, One-part alkali-activated materials: a review, Cement Concr. Res. 103 (2018) 21-34.

[32] A. Hajimohammadi, T. Ngo, A. Kashani, Sustainable one-part geopolymer foams with glass fines versus sand as aggregates, Constr. Build. Mater. 171 (2018) 223-231.

[33] S. Greiser, P. Sturm, G.J.G. Gluth, M. Hunger, C. Jäger, Differentiation of the solidstate NMR signals of gel, zeolite phases and water species in geopolymer-zeolite composites, Ceram. Int. 43 (2017) 2202-2208.

[34] I. Garcia-Lodeiro, A. Palomo, A. Fernández-Jiménez, An Overview of the Chemistry of Alkali-Activated Cement-Based Binders, 2015, pp. 19-47.

[35] J.L. Provis, J.S.J. van Deventer, Geopolymers and Other Alkali-Activated Materials, 2019, pp. 779-805.

[36] A. Palomo, P. Krivenko, I. Garcia-Lodeiro, E. Kavalerova, O. Maltseva, A. Fernández-Jiménez, A review on alkaline activation: new analytical perspectives, Mater. Construcción 64 (2014) 022.
[37] O. Burciaga-Díaz, I. Betancourt-Castillo, Characterization of novel blast-furnace slag cement pastes and mortars activated with a reactive mixture of $\mathrm{MgO}-\mathrm{NaOH}$, Cement Concr. Res. 105 (2018) 54-63.

[38] N. Li, C. Shi, Z. Zhang, D. Zhu, H.-J. Hwang, Y. Zhu, T. Sun, A mixture proportioning method for the development of performance-based alkali-activated slag-based concrete, Cement Concr. Compos. 93 (2018) 163-174.

[39] E. Coudert, M. Paris, D. Deneele, G. Russo, A. Tarantino, Use of alkali activated high-calcium fly ash binder for kaolin clay soil stabilisation: physicochemical evolution, Constr. Build. Mater. 201 (2019) 539-552.

[40] G.M. Canfield, J. Eichler, K. Griffith, J.D. Hearn, The role of calcium in blended fly ash geopolymers, J. Mater. Sci. 49 (2014) 5922-5933.

[41] I. Garcia-Lodeiro, E. Aparicio-Rebollo, A. Fernández-Jimenez, A. Palomo, Effect of calcium on the alkaline activation of aluminosilicate glass, Ceram. Int. 42 (2016) $7697-7707$.

[42] B. Walkley, R. San Nicolas, M.-A. Sani, G.J. Rees, J.V. Hanna, J.S.J. van Deventer, J.L. Provis, Phase evolution of C-(N)-A-S-H/N-A-S-H gel blends investigated via alkali-activation of synthetic calcium aluminosilicate precursors, Cement Concr. Res. 89 (2016) 120-135.

[43] R. Dabbebi, J.L.B. de Aguiar, B. Samet, S. Baklouti, Mineralogical and chemical investigation of Tunisian phosphate washing waste during calcination, J. Therm. Anal. Calorim. 137 (5) (2019) 1827-1840.

[44] N.K. Lee, H.K. Lee, Reactivity and reaction products of alkali-activated, fly ash/slag paste, Constr. Build. Mater. 81 (2015) 303-312.

[45] I. Garcia-Lodeiro, A. Palomo, A. Fernández-Jiménez, D.E. Macphee, Compatibility studies between N-A-S-H and C-A-S-H gels. Study in the ternary diagram Na2O-CaO-Al2O3-SiO2-H2O, Cement Concr. Res. 41 (2011) 923-931.

[46] B. Walkley, J.L. Provis, R. San Nicolas, M.A. Sani, J.S.J. van Deventer, Stoichiometrically controlled C-(A)-S-H/N-A-S-H gel blends via alkali-activation of synthetic precursors, Adv. Appl. Ceram. 114 (2015) 372-377.

[47] B. Walkley, R. San Nicolas, M.-A. Sani, S.A. Bernal, J.S.J. van Deventer, J.L. Provis, Structural evolution of synthetic alkali-activated CaO-MgO-Na 2 O-Al 2 O 3 -SiO 2 materials is influenced by Mg content, Cement Concr. Res. 99 (2017) 155-171.

[48] M.J. Sánchez-Herrero, A. Fernández-Jiménez, Á. Palomo, L. Klein, Alkaline hydration of C2S and C3S, J. Am. Ceram. Soc. 99 (2016) 604-611.

[49] I. García-Lodeiro, A. Fernández-Jiménez, A. Palomo, Variation in hybrid cements over time. Alkaline activation of fly ash-portland cement blends, Cement Concr. Res. 52 (2013) 112-122.

[50] J. Tailby, K.J.D. MacKenzie, Structure and mechanical properties of aluminosilicate geopolymer composites with Portland cement and its constituent minerals, Cement Concr. Res. 40 (2010) 787-794.

[51] K. Kupwade-Patil, S.D. Palkovic, A. Bumajdad, C. Soriano, O. Büyüköztürk, Use of silica fume and natural volcanic ash as a replacement to Portland cement: micro and pore structural investigation using NMR, XRD, FTIR and X-ray microtomography, Constr. Build. Mater. 158 (2018) 574-590.

[52] I. García-Lodeiro, A. Fernández-Jiménez, A. Palomo, D.E. Macphee, Effect of calcium additions on N-a-S-H cementitious gels, J. Am. Ceram. Soc. (2010).

[53] S. Greiser, G.J.G. Gluth, P. Sturm, C. Jäger, 29Si $\{27 \mathrm{Al}\}, 27 \mathrm{Al}\{29 \mathrm{Si}\}$ and $27 \mathrm{Al}\{1 \mathrm{H}\}$ double-resonance NMR spectroscopy study of cementitious sodium aluminosilicate gels (geopolymers) and gel-zeolite composites, RSC Adv. 8 (2018) 40164-40171.

[54] E. L'Hôpital, B. Lothenbach, D.A. Kulik, K. Scrivener, Influence of calcium to silica ratio on aluminium uptake in calcium silicate hydrate, Cement Concr. Res. 85 (2016) 111-121.

[55] W. Wang, F. Wang, Y. Kang, A. Wang, Enhanced adsorptive removal of methylene blue from aqueous solution by alkali-activated palygorskite, water, air, \& Soil Pollution, 2015, p. 226.

[56] X. Gao, Q.L. Yu, H.J.H. Brouwers, Apply 29Si, 27Al MAS NMR and selective dissolution in identifying the reaction degree of alkali activated slag-fly ash composites, Ceram. Int. 43 (2017) 12408-12419.

[57] C. Roosz, P. Vieillard, P. Blanc, S. Gaboreau, H. Gailhanou, D. Braithwaite, V. Montouillout, R. Denoyel, P. Henocq, B. Madé, Thermodynamic properties of CS-H, C-A-S-H and M-S-H phases: results from direct measurements and predictive modelling, Appl. Geochem. 92 (2018) 140-156.

[58] V. Sreeja, T. Smitha, D. Nand, T. Ajithkumar, P. Joy, Size dependent coordination behavior and cation distribution in $\mathrm{MgAl} 2 \mathrm{O} 4$ nanoparticles from $27 \mathrm{Al}$ solid state NMR studies, J. Phys. Chem. C 112 (2008) 14737-14744.

[59] J. Brus, S. Abbrent, L. Kobera, M. Urbanova, P. Cuba, Advances in 27Al MAS NMR Studies of Geopolymers 88 (2016) 79-147.

[60] I. Ismail, S.A. Bernal, J.L. Provis, R. San Nicolas, S. Hamdan, J.S.J. van Deventer, Modification of phase evolution in alkali-activated blast furnace slag by the incorporation of fly ash, Cement Concr. Compos. 45 (2014) 125-135.

[61] J.L. Provis, J.S.J. Van Deventer, Geopolymers: Structures, Processing, Properties and Industrial Applications, Elsevier2009.

[62] S.A. Bernal, J.L. Provis, V. Rose, R. Mejía de Gutierrez, Evolution of binder structure in sodium silicate-activated slag-metakaolin blends, Cement Concr. Compos. 33 (2011) 46-54.

[63] C. Li, H. Sun, L. Li, A review: the comparison between alkali-activated slag ( $\mathrm{Si}+\mathrm{Ca}$ ) and metakaolin (Si+ Al) cements, Cement Concr. Res. 40 (2010) 1341-1349.

[64] P. Duxson, G. Lukey, F. Separovic, J. Van Deventer, Effect of alkali cations on aluminum incorporation in geopolymeric gels, Ind. Eng. Chem. Res. 44 (2005) 832-839.

[65] P. Duxson, J.L. Provis, G.C. Lukey, S.W. Mallicoat, W.M. Kriven, J.S.J. van Deventer, Understanding the relationship between geopolymer composition, microstructure and mechanical properties, Colloid. Surf. Physicochem. Eng. Asp. 269 (2005) 47-58. 
[66] I. Lancellotti, C. Ponzoni, M.C. Bignozzi, L. Barbieri, C. Leonelli, Incinerator botton ash and ladle slag for geopolymers preparation, Waste and Biomass Valorization 5 (2014) 393-401.

[67] P. Chindaprasirt, P. De Silva, K. Sagoe-Crentsil, S. Hanjitsuwan, Effect of SiO 2 and Al 2 O 3 on the setting and hardening of high calcium fly ash-based geopolymer systems, J. Mater. Sci. 47 (2012) 4876-4883.
[68] F. Puertas, A. Fernández-Jiménez, Mineralogical and microstructural characterisation of alkali-activated fly ash/slag pastes, Cement Concr. Compos. 25 (2003) 287-292. 